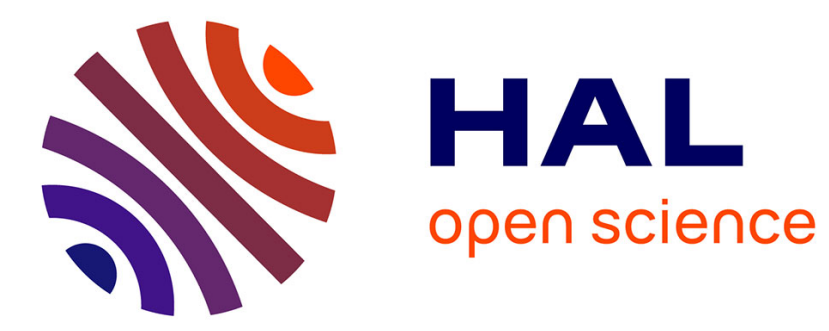

\title{
CHARACTERIZATION OF Al2O3/TA6V AND ZrO2/TA6V CERAMIC-METAL INTERFACES
}

C. Peytour, Franck Barbier, P. Berthet, A. Revcolevschi

\section{To cite this version:}

C. Peytour, Franck Barbier, P. Berthet, A. Revcolevschi. CHARACTERIZATION OF Al2O3/TA6V AND ZrO2/TA6V CERAMIC-METAL INTERFACES. Journal de Physique Colloques, 1990, 51 (C1), pp.C1-897-C1-902. 10.1051/jphyscol:19901141 • jpa-00230053

\section{HAL Id: jpa-00230053 https://hal.science/jpa-00230053}

Submitted on 1 Jan 1990

HAL is a multi-disciplinary open access archive for the deposit and dissemination of scientific research documents, whether they are published or not. The documents may come from teaching and research institutions in France or abroad, or from public or private research centers.
L'archive ouverte pluridisciplinaire HAL, est destinée au dépôt et à la diffusion de documents scientifiques de niveau recherche, publiés ou non, émanant des établissements d'enseignement et de recherche français ou étrangers, des laboratoires publics ou privés. 


\title{
CHARACTERIZATION OF $\mathrm{Al}_{2} \mathrm{O}_{3} / \mathrm{TA} 6 \mathrm{~V}$ AND $\mathrm{ZrO}_{2} / \mathrm{TA6V}$ CERAMIC-METAL INTERFACES
}

\author{
C. PEYTOUR, F. BARBIER, P. BERTHET and A. REVCOLEVSCHI \\ Laboratoire de Chimie des solides, UA CNRS 446, Université Paris Sud, \\ Bât. 414, F-91405 orsay Cedex, France
}

\begin{abstract}
Resume - Des liaisons par brasage actif ont ete realisees encre l'alliage de titane Ti-6Al.4V (TAGV) et les ceramiques $A_{2} \mathrm{O}_{3}$ et. $\mathrm{ZiO}_{2}$. L'alliage de brasure utilise a la composition cumdoAg STi. Des ieactions chimiques complexes se produlsent dans la zone interfariale et. conduisent a la formation de phases de differentes compositions. Le compose $\mathrm{Cu}_{2}\left(\mathrm{~T}_{1}, \mathrm{Al}\right)_{4} \mathrm{O}$ est observe a l'interface brasurelceramidue. A proximite du metal de base, des phases untermetalliques Cu-Ti sorit

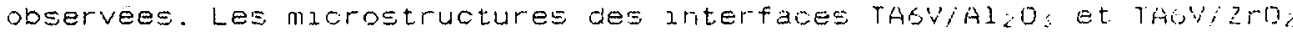
sont tres semblables alors que les proprletes micandques presentent des differences notables : la resistance a la traction mesuree pour le jolnt

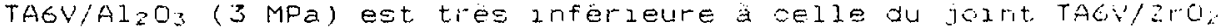
(150 MPa).

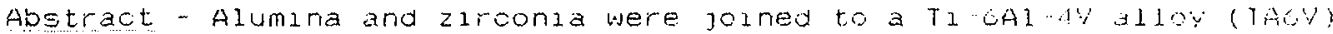
using an active braze of composition Cuw foAgusta. The triterface reglor js snown to be very complex, consisting of numerous lavere af varyln composition and thickness. The chemical interaction of the birad with

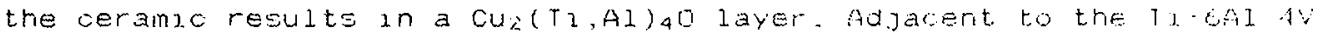
base metal, a series of cu-ri lntermetalile phases 15 cbserved. Tle

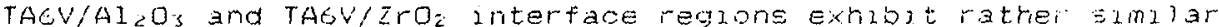
mucrostiructures. However, the mechanical propertues of the jounts in these two systems are very different. The tenslle stiength of the jolnt. is sianificantly lower tri the case of TAOV/Alzon (BMPa) than fur TAǴVi2 $\mathrm{rO}_{2}$ (150MPa).
\end{abstract}

\section{1 - INTRODUCTION}

In many current industrial applications, ceranzcs inust be yodned lo a netij ar to a metalilo alloy. Examples include engine components, elcutronjo devices and ceramic/metal composites. The processes developed to form stiron and reliable jounts have to overcome the largely difterlag pioperties of ot allics. and metals/1/. There are three major types of jounzm terhilates (1) mecharical joining, (2) djreot jolnung, or (3) indrect joinino ia, Grazing is one of the commoniy employed indirect techniates for which molat braze alloys including active elemente (e.g. Ti) were developed dn dider i. modify the chemistry of the ceramic surface and hence, to lmriove the bett.r ra of the cerarilo by the liculd braze/2,3/. The interact jon between the metal and the ceramio deternines the structume of the interface arid herice tibe properties of the system. It is therefore amportant to understarid and buntrol the chemical reactione which occur at the ceramacimetal interface. loreover. the mechanical properties of the joint have to he known for a complete characterization of the interface. The work presented here conslsts ln the identification of the microstrusture and composition of interfoulal acimponks. formed upon orazing of titarium alloy TAsy and aluilina or zirionia. Tre mecharical behaviour of the jolrte $i=$ also studied and discussed.

\section{2 - EXPERIMENTAL}

(a) Materials

The ceramacs whion were used are made by ceriam ques Technzques rianos. the

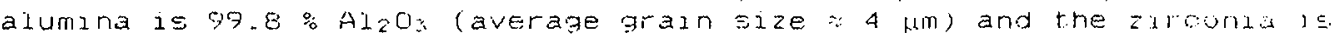
partialiy stablized with 3 mol. \% Y ${ }_{2} \mathrm{O}_{3}$ (average graln $512 e \because 0.35$ lan) The

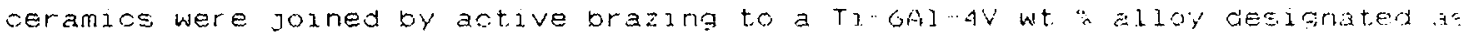

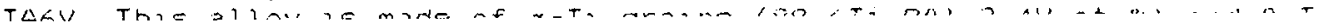


intergranular phase (78.5Ti-3.7Al-17.8V at \%). The brazing filler metal is glassy ribbon of Cu-4OAg-5Ti wt \% (about $80 \mu \mathrm{m}$ thick) and is produced by Vacuumschmelze GmbH-Germany. Thermal expansion curves of the materlals use this study are presented in Fig. 1, on which one can see a rather similar behaviour of $\mathrm{ZrO}_{2}$ and TASV.

Samples were prepared in disc form, $10 \mathrm{~mm}$ in diameter and $5 \mathrm{~mm}$ thick: The ceramic surfaces were polished to a mirror finish ( 2 um diamond) to increa wetting; the metallic surfaces had a $8 \mu \mathrm{m}$ diamond polish. Brazing was performed by heating samples for 2 to 10 minutes in a vacuum furnace $\left(\approx 3.10^{-5}\right.$ Torr) in the temperature range $850-890^{\circ} \mathrm{C}$, and subsequentIy cool, them to room temperature in 4 hours.

\section{(b) Microstructural characterization of brazed joints}

Cross sections of the TAGV/Al2 $\mathrm{O}_{3}$ and $\mathrm{TAGV} / \mathrm{ZCO}_{2}$ interfaces were characteriz by scanning electron microscopy (SEM) and electron probe microanalysis. Ir addition, transmission electron microscopy (TEM) and electron diffraction were used to image the phases at higher resolution and to give crystal structure information.

\section{(c) Mechanical strength measurements of brazed joints}

The mechanical strength of the joints was evaluated by tensile tests condu at room temperature on brazed samples having the configuration representer Fig. 2. The fracture surfaces were examined by SEM.

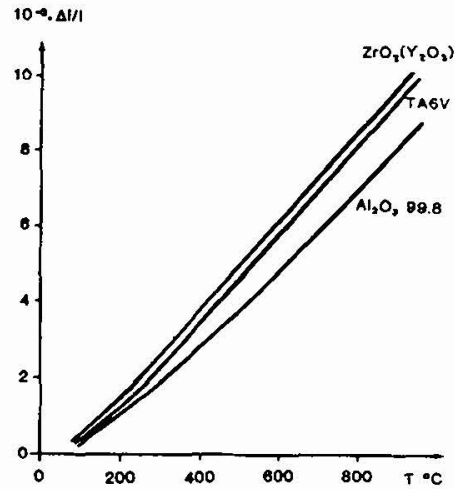

Fig. 1 -. Thermal expansion curves of $\mathrm{TASV}, \mathrm{Al}_{2} \mathrm{O}_{3}$ and $2 \mathrm{rO}_{2}$.

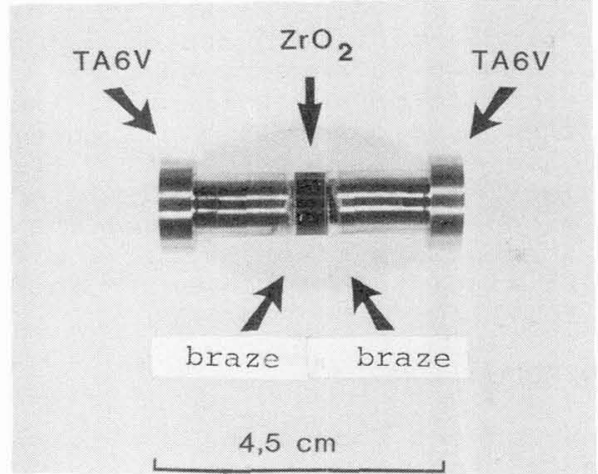

Fig. 2 .- Microgiaph showing the ter specimen.

3 - RESULTS

\section{(a) Microstructure of brazed joints}

Figure 3 iliustrates the microstructure of a TA6V/Al: O; brazement. The electron microprobe compositional line scan of this interface (Fig. 3c) indicated that complex chemical reactions occurred between braze alumina the titanium alloy. In particular, segregation of $T_{i}$ to the braze/Al $\mathrm{A}_{3}$ interface was readily seen.

Adjacent to $\mathrm{Al}_{2} \mathrm{O}_{3}$, a continuous and sinwous layer "a" ( $\approx 2-3$ um thick) whe composition is 50Ti-35Cu-15Al (at \%) was observed. TEM observation showes that layer "a" is made of equiaxed grains that are larger farther from al. (Fig. 4a). Very few dislocations were observed in the different gralns wh: were investigated. Electron diffraction indicated that phase "a" has a cuk structure with a lattice parameter $a=11.43 \pm 0.10 \mathrm{~A}$ (Table 1. Fig. Ab). crystallographic features of this phase are similar to those reported for ternary oxide CuzTi4O/4,5/. Moreover, the (TI+Al)/Cu experimental ratiov found equal to 1.9 which is in rather good agreement with the Tilcu ilia the compound $\mathrm{Cu}_{2} \mathrm{~T}_{24} \mathrm{O}$. Therefore. al though electron microprobe aralysu of oxygen is missing, our data lead to the conolusion that laver "a" 25 the"

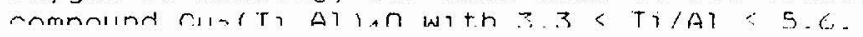



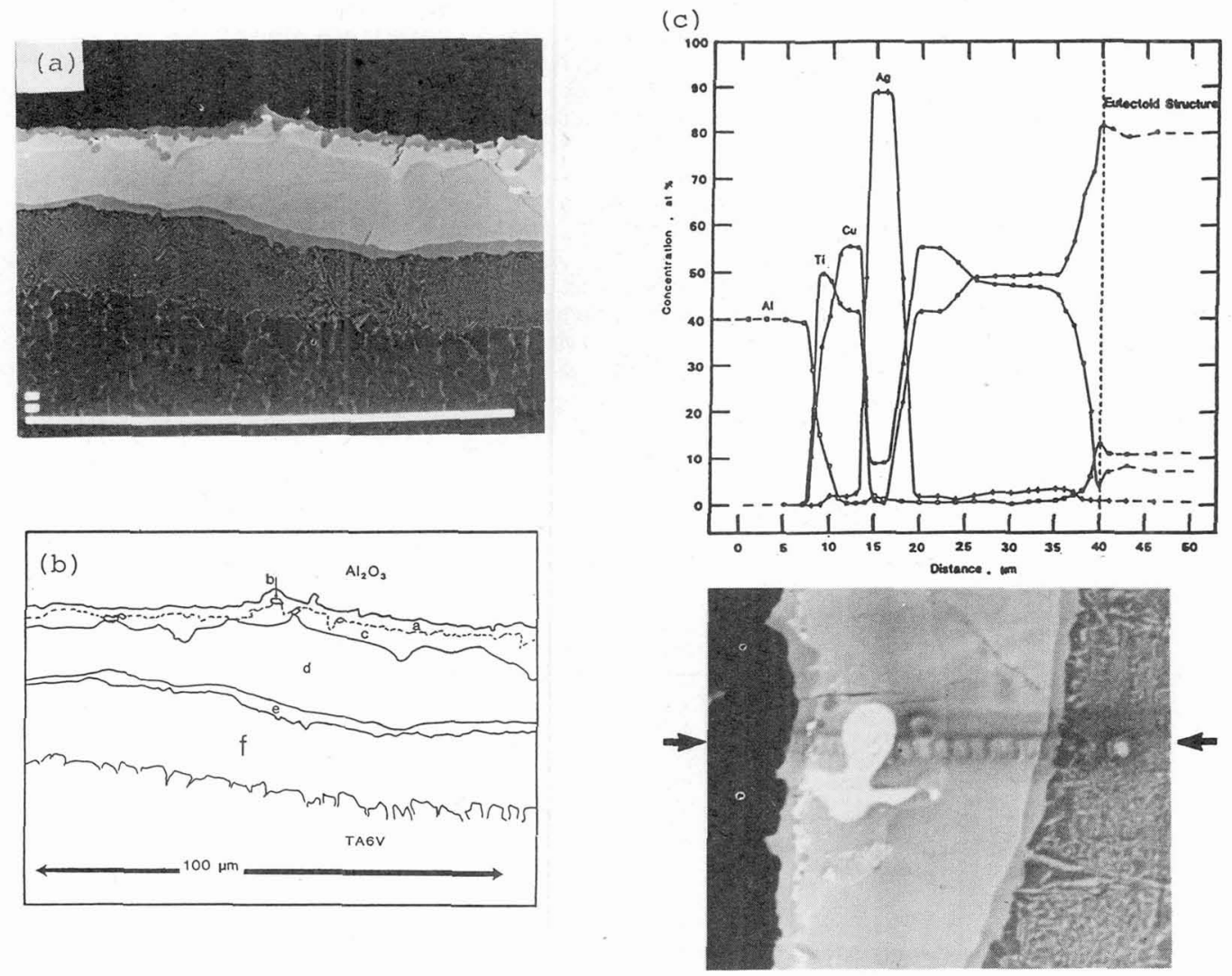

Fig. 3 - Cross-section of the TAGV/CU-Ag-Ti/Al2 $\mathrm{O}_{3}$ interface after brazing : (a) SEM micrograph, (b) Schematic drawing, (c) Microprobe Iine scans showing the composition variation across the interface.
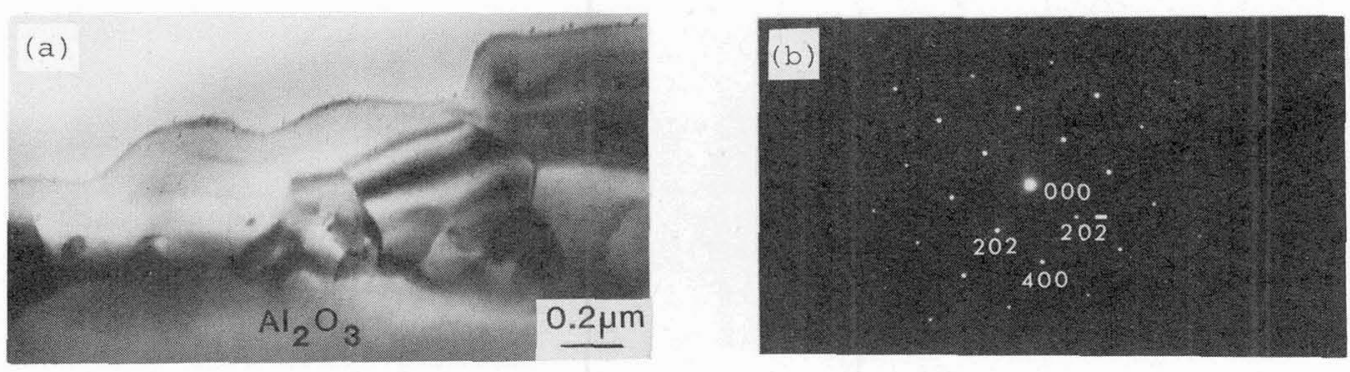

Fig. 4 - (a) TEM micrograph showing the microstructure of the $\mathrm{Cu}_{2}\left(\mathrm{TI}_{1}, \mathrm{Al}_{4} \mathrm{C}_{\mathrm{O}}\right.$ layer adjacent to $\mathrm{Al}_{2} \mathrm{O}_{3}$, (b) Electron diffraction of $\mathrm{Cu}(\mathrm{Ti}, \mathrm{Al})_{4} \mathrm{O}$; the zone axis $1 \leqslant[010]$. 


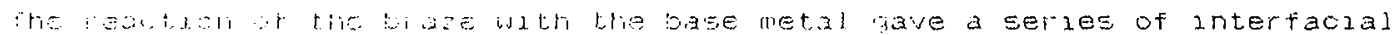
priases. Agiment to Trich, a lamellar structure ("f") was formed. It consis of ari i la phase (black phase ln rig. 3a) and a phase "e" whose coinpositic 6\%.81. 24. cicu 5.6Al at \%. Clectron diffraction showed that " $\epsilon$ " has an hexagonal structuie (Table 1). A review of the literature relative to crys Structuies of intermetal.110 phases / o/ indicated that this phase has orvatallographic onaracteristics similar to those of Tizsn and Nussn. Taki into accolint that the $(T 1+A 1) / C u$ experimental ratio 15 approximately $3: 1$, we can propose the formulation ( $T$ i, Al) scu for phase "E". Farther, we find phases " $e$ " " $d$ " and " $c$ " which are essentialjy made of cu and Ti (Fig. 3o). phases " $e$ " and " $q$ " have ooth a tetragonal structure (Table 1) which is consistent respectivejy with that of the TizCu and TiCu compounds. Concer now layer "o", it can be deduced from Fig. 3c that this layer is the compc TizCua (Table 1). However. In some areas of the "c" layer, grains containi up to 12 at \% Al were also identitied. These gralns, which have an oithornombio structure (Table 1), can be identified with the $T i(C U, A I) 4$ compound. Last, some discrete particles "b" which are an Ag-rich solutic are emberded in layer "c".

Table 1

Characterjstics of the phases formed in the TAGV/Cu-Ag-T2/A $2 \mathrm{O}_{3}$ jolnt.

\begin{tabular}{|c|c|c|c|c|c|}
\hline 1.ayers & $\begin{array}{c}\text { Crystal } \\
\text { structures }\end{array}$ & $\begin{array}{l}\text { Latt } \\
a\end{array}$ & $\begin{array}{c}\text { parar } \\
\text { b }\end{array}$ & $\begin{array}{c}-S(A) \\
c\end{array}$ & Phases \\
\hline $\begin{array}{l}a \\
b \\
0 \\
0 \\
a \\
e \\
f\left\{\begin{array}{l}\alpha \cdots+1 \\
\varepsilon\end{array}\right.\end{array}$ & $\begin{array}{l}\text { cublo } \\
\text { cubic } \\
\text { tetragonal } \\
\text { orthorhomblo } \\
\text { tetragonal } \\
\text { tetragonal } \\
\text { rexagonal } \\
\text { nexagonal }\end{array}$ & $\begin{array}{r}11.43 \\
4.07 \\
3.12 \\
4.52 \\
3.11 \\
2.76 \\
2.95 \\
5.92\end{array}$ & 4.46 & $\begin{array}{c}17.9 \\
12.08 \\
5.9 \\
10.85 \\
4.68 \\
4.73\end{array}$ & 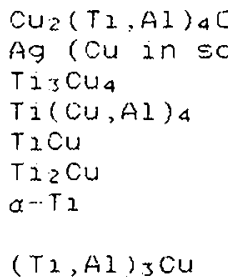 \\
\hline
\end{tabular}

The microstructure of the TASV/ZROZ brazements exhibited interfacial characteristics which are very similar to those observed in the system rAsV/Alios, the same interfacial reaction products being formed in the two systems. However, soine features are different:

- Ir as worth noting that the zirconia olose to layer "a" is blackened a brazing, whach indicates oxygen deficlenoy for the ceramic. Thus, ther a source of oxygen at the oraze/ceramic interface because of the oxyge mobjlity in z.roz. Reversely, no diffusion of zirconium in the braze wa observed.

- In both systems, aluminum zs detected in interfacial layers close to $t$ ceramic. However, the Al concentration is lower in the case of $T A G V / 2 r$ thar for TAGV/ALiD?. This trend indicates some diffusion of Al from A] $2 \mathrm{O}_{3}$ into the braze.

(b) Tensile stiength of brazed joints

As cian be seen in Table 2 , the mechanical behaviour of the two types of samples 15 very different. The fracture surfaces of the samples are also $f$ different (fig. 5). This can be directiv related to the differerice between thermal exparision coefficients of $\mathrm{Al}_{2} \mathrm{O}, 2,2 \mathrm{O} \mathrm{O}_{2}$ and TAbV (FIg. 1 ).

It carl be eeen that in the case of $A_{2} O_{3}$, fracture has taken place within ceramlo and ls mostly intergranular (Fig. Sa). Rupture results of propagat of oracke already formed in the ceramic near the interface upon cooling fr the brazing temperature. In the case of $2 \mathrm{rO}_{2}$, all samples fractured withir Toint area near the $\mathrm{ZiO}_{2}$ surface and in no case rupture had propagated inslie zirconia. Fig. 5b shows a typical fracture surface made of two zone one predominantiy regular, the other puckered as oan be seen at a higher magnification in Fig. So. 
Table 2

Tensile strength of $\mathrm{TAGV} / \mathrm{Al}_{2} \mathrm{O}_{3}$ and $\mathrm{TAGV} / \mathrm{ZrO}_{2}$.

\begin{tabular}{|l|c|c|c|}
\hline Metal/ceramic & Number of specimens & Brazing temperature & $\begin{array}{c}\text { Tensile strength } \\
\left({ }^{\circ} \mathrm{C}\right)\end{array}$ \\
\hline TAGV $/ \mathrm{Al}_{2} \mathrm{O}_{3}$ & 10 & $870 \pm 10$ & $3 \pm 1$ \\
TAGV/ZrO2 & 7 & $870 \pm 10$ & $150 \pm 50$ \\
\hline
\end{tabular}
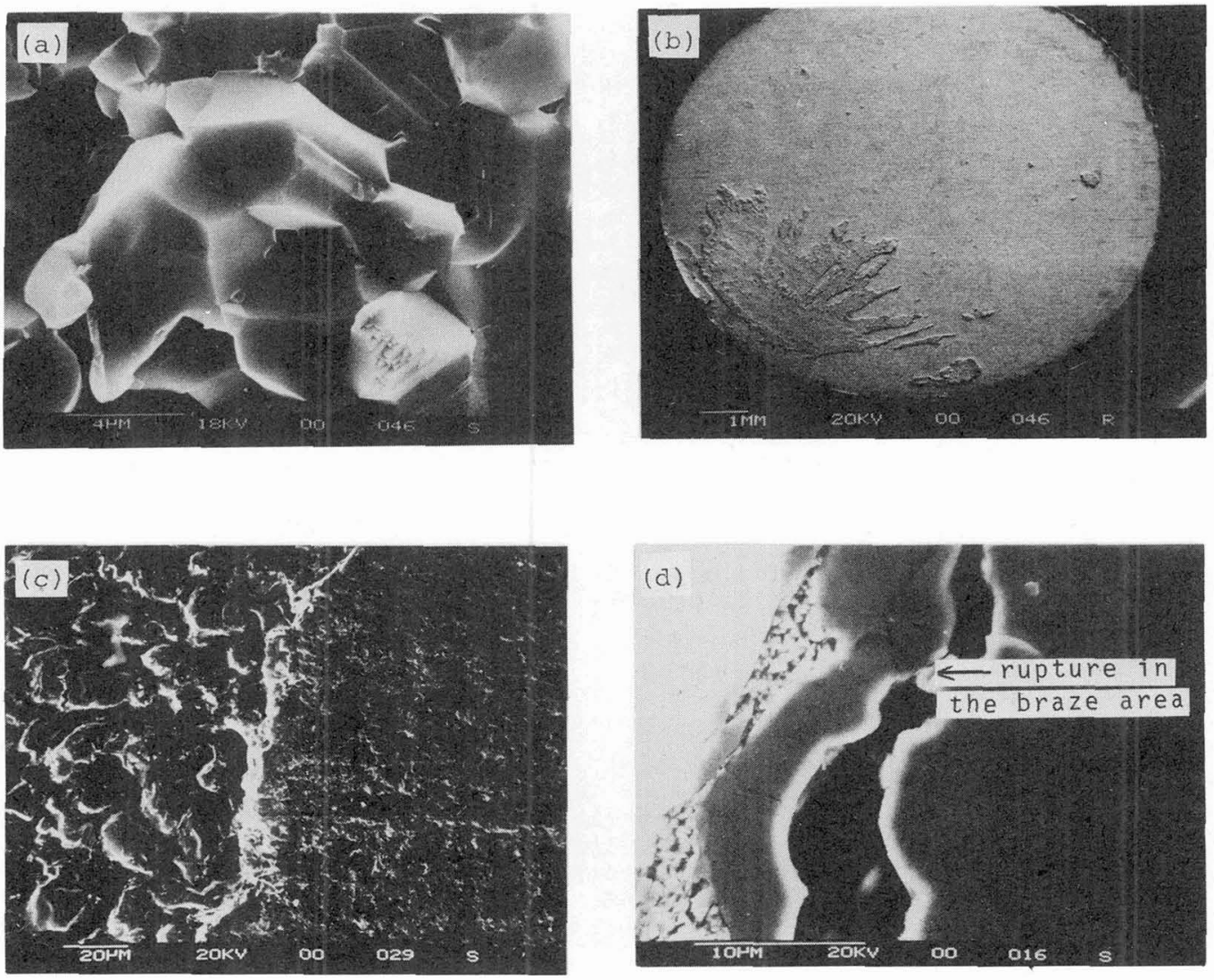

Fig. 5 - (a) Fracture surface of a TAGV/Al2 O3 sample, (b) Fracture surface of a $T A G V / Z \mathrm{rO}_{2}$ sample (ceramic part), (c) Higher magnification of the micrograph shown in (b), (d) Perpendicular section of the surface fracture (metal part).

Energy dispersive $X$-ray analysis performed on the surface of the metal part of the ruptured test specimen indicates that the puckered portion of the fracture is made of Cu-Ti phases, as shown in Fig. 5d. As for the predominantiy regular part of the fracture, analysis indicates for Ti, Cu and Al compositions similar to those of phase "a". The complementary part of this fracture on the ceramic part of the broken sample was also analysed, and the presence of Ti, $\mathrm{Cu}$, Al was detected. This result indicates that the fracture occurred oredominantlv within ohase "a" in the close vicinity of zirconia. 
4 DIscussion

The interface region in the TAGV/AlzOs and TAGV/ZROz brazements is very complex, and consists of numerous layers of varying composition and thick This result indicates a reactivity of the braze alloy with both the ceram and the titanium alloy.

The reactivity of the cumAg-Ti braze with $\mathrm{Al}_{2} \mathrm{U}_{3}$ or $2 \mathrm{rg}$ leads to the form of the Cuz (TI, Al) ${ }_{4} \mathrm{O}$ oxide phase. Such a reaction is not yet weli defined a thermodynamical point of view. Nevertheless, $2 t$ can be assumed that Tl segregates from the molten braze to the ceramio surface because of its affinity for oxygen and that oxygen from alumima or zirconia is dissolved the braze. Thence, dissolved oxygen may react with titanium to produce Cua(i1,Al) 40 /7/. Such a compound may serve as a transition layer and a wettable surface that promotes bonding between the ceramic and the rhev a The base titanium alloy acts as a source of Ti fo the braze, leading to $t$ formation of Cu-Ti intermetalilo phases. The existence of TizCu, TICU, $\mathrm{Ti}(\mathrm{CU}, \mathrm{Al})_{4}$ and $\mathrm{Ti}_{3} \mathrm{Cu}_{4}$ and $\mathrm{i}$ a in good agreement with the stable compoumds present in the Ti-Cu phase diagram/8!.

Concerning row the tensile tests, it is also worthwhile to note that ziro seems to accomodate the stresses introduced by the brazing process, in contrast. with what was cuserved for TA6vialumina joints prepared with a similar procedure. The better mechanical behaviour observed with zirconla consistent with the slmilar thermal expansion coefficients of Tasi and zirconia. We also noted a partial transformation of the initial tetragona form of zirconia into a monoclinic strwcture, and it is well known that $s$ transformation inoreases the resistance to orack propagation in 2 ro2/9/.

\section{5 - CONCLUSION}

The different anterfacial phases formed upon brazing of TACV to zroz and to Alla: were characterized. The chemical interastion cf the braze with $t$ cerama results in a Cua(TI,Al) $\mathrm{C}$ o layer. Adjacent to tre base metal. a sequence of Cu-Tl intermetalilo phases is observed. The mecharical piroper of the jolnte an these two systems are very different. In the case of the rateV/Ziri joints, a tensle strength of lso MPa was measuied. This value hagh enough for considering apolzcation of the brazing procedure to real systens.

\section{REFTERNCES}

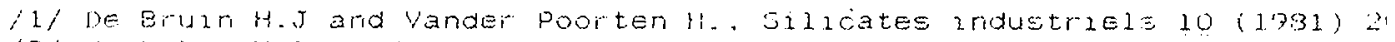

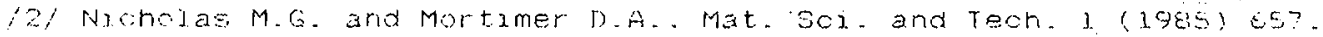

13/ Mzuhaia H. and Huebel E., Welding J. 10 (1980) 43 .

'4/ Muellei M.H. and Knott H.W. Trans. of the Met. Soo, of aIME 227 (196.

IS: Kaufiman M.J. and Shuld R.D., Met. Trans. A, 17 A (1386) 575.

icf Pearson W.E., Handbook of Crystallogiaphio Data for Intermatallie pha: ed. F. Vliai and L.D. Calvert. ASM, Metala Park, onio (19BS).

'T Peytoui C., Earbier F. and Revoolevechi A., to he fublished an J. of 1 Researon (january 1980 ).

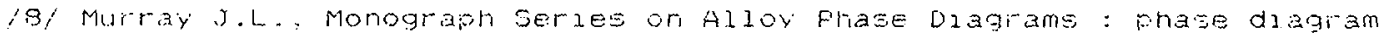
bu rar tutanjum al10ye, ed. J.L. Murray, ASM, Metals park, ohıo, p. 8 ! $(1.937)$

ï: Ruhle M. and Hever A.H., Science and Techrology of ziroonza II, Advances in Ceramucs 1.2 (1984) 14. 